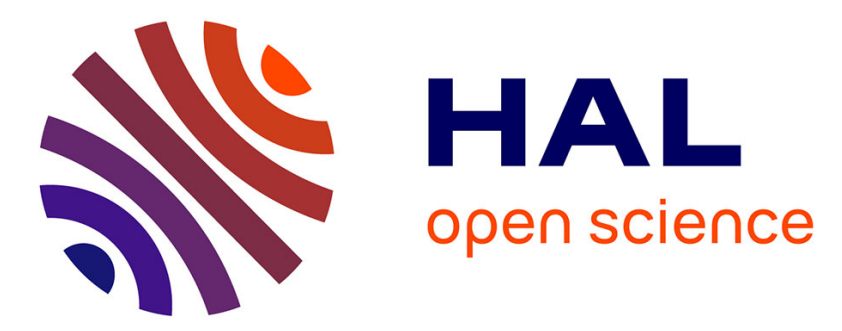

\title{
Multi-temporal dynamics of suspended particulate matter in a macro- tidal river Plume (the Gironde) as observed by satellite data
}

Sorin Constantin, David Doxaran, Anna Derkacheva, Stefani Novoa, Héloïse Lavigne

\section{To cite this version:}

Sorin Constantin, David Doxaran, Anna Derkacheva, Stefani Novoa, Héloïse Lavigne. Multitemporal dynamics of suspended particulate matter in a macro- tidal river Plume (the Gironde) as observed by satellite data. Estuarine, Coastal and Shelf Science, 2018, 202, pp.172-184. 10.1016/j.ecss.2018.01.004 . hal-01830542

\section{HAL Id: hal-01830542 \\ https://hal.sorbonne-universite.fr/hal-01830542}

Submitted on 5 Jul 2018

HAL is a multi-disciplinary open access archive for the deposit and dissemination of scientific research documents, whether they are published or not. The documents may come from teaching and research institutions in France or abroad, or from public or private research centers.
L'archive ouverte pluridisciplinaire HAL, est destinée au dépôt et à la diffusion de documents scientifiques de niveau recherche, publiés ou non, émanant des établissements d'enseignement et de recherche français ou étrangers, des laboratoires publics ou privés. 


\title{
Multi-temporal dynamics of suspended particulate matter in a macro- tidal river Plume (the Gironde) as observed by satellite data
}

\author{
Sorin Constantin a, b, *, David Doxaran a , Anna Derkacheva a , Stéfani Novoa a, \\ Héloïse Lavigne ${ }^{c}$ \\ a Laboratoire d'Océanographie de Villefranche, UMR7093, CNRS-UPMC, France \\ b TERRASIGNA, Bucharest, Romania \\ ${ }^{\mathrm{c}}$ Royal Belgian Institute for Natural Sciences OD-Nature, Belgium
}

Keywords:

Suspended particulate matter

Macro-tidal river plume

MODIS

SEVIRI

Ocean color

\section{A B S T R A C T}

The Gironde River plume area is unique in terms of Suspended Particulate Matter (SPM) dynamics. Multiple factors contribute to the variations of SPM at multiple time scales, from river outputs to wind stress, currents and tidal cycles. The formation and evolution of the Maximum Turbidity Zone (MTZ) inside the estuary also plays a significant role. Thus, detailed analyses and monitoring of the region is important for better understanding the mechanisms governing the turbid plume dynamics, for proper future management and monitoring of SPM export from the estuary to the coastal ocean. In this study we use an unprecedented volume of satellite data to capture and better understand the dynamics of the river plume. We combine two types of satellite information in order to achieve these goals: data collected by the Moderate Resolution Imaging Spectroradiometer (MODIS) and the Spinning Enhanced Visible and Infrared Imager (SEVIRI) sensors. The integrated information allows accounting for multiple time scales, i.e. from seasonal to diurnal cycles. We show and parameterize the overall effects of river discharge rates over the plume extension. Seasonal variations are also analyzed and an overall relationship between river discharge rates and plume magnitude is computed. For the first time, we clearly observe and explain the diurnal cycle of SPM dynamics in the river plume. Despite the limited capabilities of the SEVIRI sensor, geostationary data was successfully used to derive such information and results similar to in-situ datasets were obtained. The same patterns are observed, with significant increase in SPM plume during spring/ebb tide periods. Results from our study can be further used to refine sediment transport models and to gain a better perspective on the ecological implications of the sediment output in the continental shelf area.

\section{Introduction}

River mouths are key areas of the global ocean associated with highly dynamic physical, chemical and biological processes. They represent the main sources of sediments for the adjacent coastal shelf areas. Thus, it is utmost important to better understand the laws that govern these mechanisms, for a proper future management of such regions. The Gironde Estuary, one of the largest in Europe, represents an important source of sediments for the outer coastal area, namely the continental shelf of the Bay of Biscay. The

\footnotetext{
* Corresponding author. Postal address: 3 Logofat Luca Stroici Street, Bucharest, Romania.

E-mail address: sorin.c.geo@gmail.com (S. Constantin).
}

massive solid discharge, estimated at around 2.3 million tons per year, most of them (1.5 million tons) in suspension (Froidefond et al., 1998; Doxaran, 2009), helps the formation of an extensive Suspended Particulate Matter (SPM) plume at the estuary mouth. Its extension can reach tens of kilometers (Froidefond et al., 1998, 1999). This magnitude is controlled by several factors, such as the sediment export from the estuary (which is determined both by the river discharge rates and by the location of the Maximum Turbidity Zone inside the estuary), the water currents (fluvial or tidal), wind stress and waves. The hydrographic structure, meaning the variability of water temperature and salinity, plays also an important role in vertical and horizontal distribution of suspended sediments on the shelf (Castaing et al., 1999).

Within the present study we are proposing a new approach to study the SPM dynamics in the plume of the Gironde macro-tidal 
estuary based on Earth Observation data. The novelty of the study comes from the combined use of two different types of satellite information for achieving an overall goal: analyze the Gironde SPM plume dynamics over multiple time scales. First, an unprecedented number of quality ocean color satellite data, acquired by MODIS (Moderate Resolution Imaging Spectroradiometer), at relatively high spatial resolution, $250 \mathrm{~m}$, is used. This is the first initiative to exploit such a big archive for the Gironde area. Previous studies (Froidefond et al., 1998, 1999; Hermida et al., 1998) were based on limited amount of satellite images and could capture mainly specific events, without the capability of gaining an overall understanding of the SPM dynamics. Second, data from the SEVIRI (Spinning Enhanced Visible and Infrared Imager) geostationary sensor is used for further analysis. This is yet another novelty brought by the study, since Gironde plume area has never been analyzed using such high-frequency satellite datasets, in terms of temporal coverage. The methodology can be successfully applied also to other similar areas. While these types of endeavors based on MODIS data have been extensively proved for other areas (e.g. Adour - Petus et al., 2010; Mekong - Loisel et al., 2014; Yangtze Feng et al., 2014; Mackenzie - Doxaran et al., 2015; Rio de la Plata Dogliotti et al., 2016; Danube - Constantin et al., 2017), geostationary data still has a limited use for ocean color applications.

SEVIRI, the radiometer onboard the geostationary platform METEOSAT Second generation, dedicated especially to meteorological applications, has only limited been used for ocean color studies (Vanhellemont et al., 2014; Ody et al., 2016), mainly due to its coarse spectral and radiometric resolutions. Previous studies based on SEVIRI data addressed the variability of water quality parameters, such as SPM, turbidity and attenuation of photosynthetically available radiation $\left(K_{\mathrm{PAR}}\right)$ in the North Sea. Neukermans et al. (2009) initially showed the feasibility of using SEVIRI information to retrieve SPM, which was the first proof of concept for such analysis in turbid waters. The diurnal variability of turbidity was as well analyzed, again, for the North Sea region (Neukermans et al., 2012; Ruddick et al., 2013). Data fusion between SEVIRI and MODIS was considered (Vanhellemont et al., 2014) and it was proven that the synergy between them can account for high temporal and spatial variations of ocean color parameters. These previous studies focused mainly on methodological aspect (such as atmospheric corrections and uncertainties associated to water quality parameters estimations) and analyzed the temporal and spatial variability of SPM or turbidity as a consequence of resuspension processes determined by the tidal cycle. Within this present study a river plume area in a macro-tidal region is analyzed, where SPM dynamics are governed not only by resuspension but mainly by sediment outputs from inside the estuary. Thus, the river discharge rates and the evacuation towards the continental shelf of the sediment mass accumulated inside the estuary have to be accounted for, as well.

Although not used for this study, it is important to mention the Geostationary Ocean Color Imager (GOCI) in order to have a better perspective on the general context regarding water quality applications based on geostationary satellite data. GOCI is the only true ocean color sensor in geostationary orbit today and it was launched by the Korea Aerospace Research Institute (KARI) in June 2010. It can provide hourly observations, at $500 \mathrm{~m}$ spatial resolution, over the region of east China, Korea and Japan. The spectral bands configuration is much more suited for ocean color applications, compared to SEVIRI, with 8 channels that cover the visible and near-infrared regions. Therefore, the studies using GOCI concerning water quality and especially SPM dynamics are more numerous and cover multiple coastal areas, from shallow waters dominated by resuspension processes to estuaries (He et al., 2013; Choi et al., 2014; Cheng et al., 2016; Eom et al., 2016). It comes to show the true potential of an ocean color satellite sensor and sets up the target for future possible studies in the European regions. GOCI was successfully used in highly turbid coastal areas and daily to seasonal observations were drawn (Choi et al., 2014). A micro-tidal estuary was also analyzed - Yalu River (Cheng et al., 2016) and high quality conclusions regarding the diurnal and seasonal SPM cycles were revealed.

The objectives of the present study are (i) to analyze Gironde SPM plume dynamics in correlation with various forcing factors, at greater detail than previously achieved and (ii) to test the capability of different satellite sensors to capture such dynamics and compare with in-situ measurements (in terms of observed patterns), with a special focus of geostationary satellite data, first time used in a study concerning the Gironde River plume.

\section{Data and methods}

\subsection{Study area}

The exact Area of Interest (AOI) overlaps the continental shelf in close proximity of the mouth of the Gironde (Fig. 1). Due to large sedimentary deposits, the underwater topography is almost flat, with very low slopes. The mouth of the estuary is narrower than the inside part, therefore the depths within the two channels (one in the south and the other in the north part, which is navigable) are higher: $20-30 \mathrm{~m}$, compared to $5-10 \mathrm{~m}$ in the inner part. This has a direct implication on the water currents variations.

In terms of sedimentary characteristics, the AOI is mainly formed by sands and finer particles, such as clays, which were deposited as a function of the fluvial and tidal currents, with the smaller sediments transported further offshore. In the northern part, the AOI reaches the southern limit of the Grande Vasière - the "large mud patch", a large sedimentary depositional area (Castaing

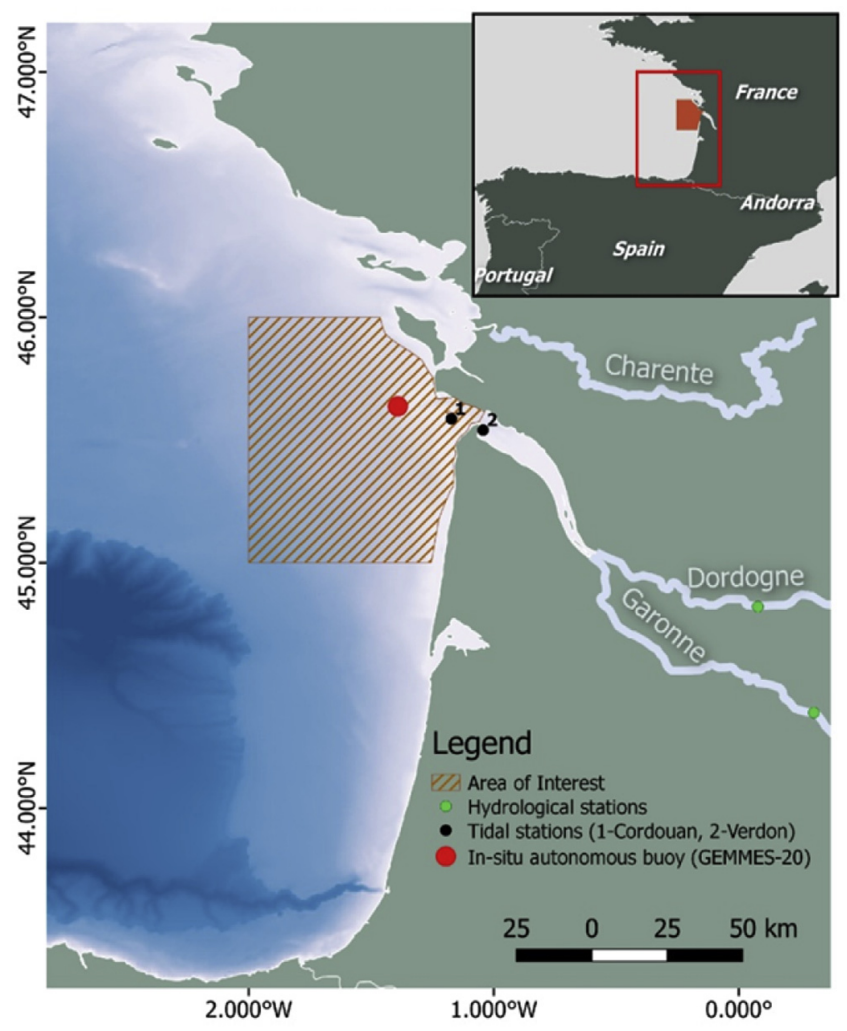

Fig. 1. Location of the area of interest. 
et al., 1999). Right in front of the estuary mouth, at depths between 30 and $70 \mathrm{~m}$, West and South-Gironde mud patches can be found (Lesueur et al., 1996). The fluvial input plays a significant role in all these processes. The hydrographic basin of the estuary is formed by two major rivers that merge in order to form the Gironde: the Garonne and the Dordogne. Their combined drainage basin sums up to approximately $71,000 \mathrm{~km}^{2}$. The maximum liquid discharge rates are recorded during winter and spring periods (up to $1450 \mathrm{~m}^{3}$ ) $\mathrm{s}$ average for January), while the lowest water levels are a characteristic of the summer period $\left(230 \mathrm{~m}^{3} / \mathrm{s}\right.$ in August). Overall, the maximum combined liquid discharge can reach maximum values of $7500 \mathrm{~m}^{3} / \mathrm{s}$. Suspended particles brought by the fresh water are frequently accompanied by bacteriologic and organic pollutants and even by heavy metals, such as copper, mercury, zinc and especially cadmium coming from the ancient zinc mines (Agence de l'Eau Adour Garonne, 1994; Froidefond et al., 1998; Lafon, 2009; Strady et al., 2011). Thus, fluvial waters have a significant impact as well on all living organisms in the continental shelf region.

The macro-tidal regime of the area is characterized by an asymmetric tidal period of approximately $12 \mathrm{~h} 25 \mathrm{~min}$ and a maximum tidal range that can reach $6 \mathrm{~m}$ at the estuary mouth. Current velocities associated with tidal dynamics can go up to $5 \mathrm{~m} / \mathrm{s}$ at the surface. These currents are the most important factor controlling the sediment transport in the area, since the amount of water introduced inside the estuary, during flood, varies between 47,000 and $85,500 \mathrm{~m}^{3} / \mathrm{s}$ (from neap to spring tide), which accounts for more than 50 times the fluvial discharge (Froidefond et al., 1998; Doxaran, 2009). Periods with maximum tidal current speeds are longer during ebb $(2 \mathrm{~h})$, than during flood $(0.5 \mathrm{~h})$. Inversion of tidal current direction occurs $1 \mathrm{~h}$ after the high tide and $1 \mathrm{~h} 30 \mathrm{~min}$ after the low tide (Petus, 2009).

Wind stress is another environmental agent that can influence the turbid plume evolution. Within the AOI, the general direction of the wind is from the northern sector (northeast, north and northwest), while the average speed is between 2 and $4 \mathrm{~m} / \mathrm{s}$, rarely exceeding $10 \mathrm{~m} / \mathrm{s}$. The increased dynamics of winds at short time scales makes their seasonal tendencies difficult to predict (Hermida et al., 1998).

The main sources of SPM in the continental shelf adjacent to the mouth of the Gironde Estuary are river solid discharge and coastal erosion. The sediments brought by the rivers are first trapped inside the estuary to form the Maximum Turbidity Zone (MTZ) (Doxaran, 2009; Doxaran et al., 2009). The location of the MTZ varies along the year and it controls most of the SPM export from inside the estuary to the coastal ocean. The turbid plume was analyzed and defined by multiple studies (Froidefond et al., 1991, 1999; Hermida et al., 1998; Petus, 2009) as a mass of fluvial freshwater with higher values of turbidity that flows into a marine environment. Once out of the estuary, the shape and direction of expansion of the turbid plume are dictated by currents (regional ones or locally induced by the wind, the tides and density gradients) (Froidefond et al., 1998, 1999; Lazure and Jegou, 1998; Lafon, 2009; Petus, 2009; Petus et al., 2010). This expansion occurs at multiple vertical levels. Therefore, a bottom (nepheloid) plume, a middle one and a surface plume are formed. Using satellite data, only observation on the SPM values in the surface water column can be made. Therefore, all the results of this study refer only to this surface plume, which has a vertical height of 5-15 m, decreasing towards the offshore areas, and it is less extended than the bottom one (Froidefond et al., 1998). The optical properties of the SPM plume are dominated by light absorption and scattering by nonalgal particles. Organic matter accounts only for approximately $2 \%$ of the total mass of suspended particles, with concentrations ranging from 1 to $3 \mathrm{mg} / \mathrm{m}^{3}$; CDOM (Colored Dissolved Organic Matter) concentration is also negligible (Froidefond et al., 1998 , 1999; Doxaran et al., 2002). The mineralogic composition of the non-organic particles is dominated by quartz, micas silts and clays (Agence de l'Eau Adour Garonne, 1994; Froidefond et al., 1998). The particles are grouped into two major categories, depending on their size: $<2 \mu \mathrm{m}$ (47\%) and between 2 and $15 \mu \mathrm{m}$ (40\%). Aggregation of particles through organic matter can lead also to much higher overall dimensions, from 100 to $500 \mu \mathrm{m}$. It was previously shown, however, that there is no direct relationship between particles size in the surface waters and the total concentration of SPM (Castaing et al., 1999). Inside the estuary the concentration of SPM can go as high as $2000 \mathrm{~g} / \mathrm{m}^{3}$ (within the Maximum Turbidity Zone) (Agence de l'Eau Adour Garonne, 1994; Doxaran, 2009), or even up to $>3000 \mathrm{~g} / \mathrm{m}^{3}$, as documented by other authors (Jalon-Rojas et al., 2015). This value decreases to approximately $100 \mathrm{~g} / \mathrm{m}^{3}$ close to the mouth and down to $5 \mathrm{~g} / \mathrm{m}^{3}$ at the limit of the exterior plume.

The effect of the winds on the morphology and direction of the turbid plume was previously shown (Froidefond et al., 1998; Lazure and Jegou, 1998), without any solid evidence on the influence that they have on the magnitude of the extension. We know that, during summer, the plume is frequently oriented south due to the northern winds, while during winter the dominant orientation is north and north-west due to overall density currents and the predominant winds.

\subsection{Satellite data and products}

In-situ measurements are an important source of information for monitoring the SPM evolution in specific locations, but, apart from the significant costs implied, they cannot give an overall synoptic view over the entire area. Remote sensing data is one alternative that can complement the in-situ sampling efforts. Multiple types of ocean color satellite information need to be considered, covering a wide range in terms of spatial, temporal and spectral resolutions. In order to achieve the goals of the present study, two types of satellite data were used: MODIS and SEVIRI. Additionally, several other auxiliary in-situ datasets were considered, all of them described below.

MODIS, apart from the vast archive available today, starting 2000 for Terra platform and 2002 for Aqua, offers also the capability of observing the AOI (providing there is no cloud cover) at least two times per day (even three times, for overlapping orbits), roughly between 11:00 and 13:00 UTC. Available in-situ measurements and previous studies (Froidefond et al., 1998, 1999; Castaing et al., 1999) have shown that the SPM concentration range inside the turbid plume generally goes up to approximately $50-60 \mathrm{~g} / \mathrm{m}^{3}$. Therefore, in order to estimate the SPM values using satellite information, an empirical linear relationship, based only on the red band (centered at $\lambda=645 \mathrm{~nm}$, with $250 \mathrm{~m}$ spatial resolution) was used (Novoa et al., 2017), without the need for switching also to NIR derived information (Dogliotti et al., 2015; Novoa et al., 2017):

$$
\begin{aligned}
\operatorname{SPM}\left(\mathrm{g} \times \mathrm{m}^{-3}\right) & =511.9 \times \mathrm{R}_{\mathrm{rs}} 645\left(\mathrm{r}^{2}=0.88, \mathrm{NRMSE}=12.18 \%, \mathrm{n}\right. \\
& =21 ; \mathrm{n} \text { represents the total number of points } / \text { match }- \text { ups used })(\text { Novoa et al., } 2017)
\end{aligned}
$$


Multiple studies have successfully used a similar approach to determine either turbidity or SPM in moderately turbid waters (Dorji and Fearns, 2016), therefore it was considered to be appropriate for our study also. Previous authors used also the green spectral band to retrieve SPM in the Bay of Biscay (Gohin et al., 2005; Gohin, 2011), but such approach might underestimate the higher concentrations close to the coast and river mouth. For the atmospheric correction, the MUMM algorithm was used (Ruddick et al., 2000), as implemented in SeaDAS 7.3 software. While for areas inside the estuary an atmospheric correction based on SWIR (Short-Wavelength InfraRed) bands approach is most suitable (Novoa et al., 2017), for the plume area the MUMM algorithm performs best, due to lower SPM concentrations. Five complete years of MODIS information were processed (2005, 2008, 2009, 2010 and 2011), in order to cover all possible ranges of river discharge rates and tidal conditions. It corresponds to a total number of 1261 usable images (completely or partly cloud-free) (Table 1). Monthly SPM composite products were computed as an average of all the layers available for each specific month. Averaged pixels which were based on less than 3 individual values were masked out.

SEVIRI sensor is capable of acquiring an image over the AOI every $15 \mathrm{~min}$, therefore it can be potentially used to observe SPM dynamics at unprecedented time scales (Ruddick et al., 2013). The spectral band covering the $560-710 \mathrm{~nm}$ region, at $3 \times 5 \mathrm{~km}$ spatial resolution, was used hereafter. Raw full disc SEVIRI data for bands VIS0.6, VIS0.8 and SWIR1.6 are downloaded from EUMETSAT and transformed into binary format. Atmospheric correction algorithm described by Neukermans et al. (2009) and specifically developed for SEVIRI was applied to the region of interest to retrieve water leaving reflectances in the red bands (VIS0.6). This algorithm is based on data from VISO.6 and VISO.8 (near infra-red) bands and used the assumption of a constant ratio for marine reflectances.

A total of 148 daily SEVIRI products for water leaving reflectances were analyzed, each containing multiple layers $15 \mathrm{~min}$ apart (approximately 50 each day). Most of them cover the time period from November 2016 to March 2017 (only 3 products from March 2014 were used, as well). The selection of the period was based on the fact that during these months in-situ data (described below) were collected. Estimation of SPM concentration was performed using an existing regional relationship:

$$
\begin{gathered}
\mathrm{SPM}\left(\mathrm{g} \times \mathrm{m}^{-3}\right)=\frac{28.92 * \mathrm{R}_{\mathrm{rs}} 625}{\left(1-\mathrm{R}_{\mathrm{rs}} 625\right) / 15.22} \quad\left(\mathrm{r}^{2}=0.87,\right. \\
\mathrm{NRMSE}=10.9 \%, \mathrm{n}=22)
\end{gathered}
$$

Selected MODIS and SEVIRI data do not overlap since it is not an objective of this current study to make any comparison between

Table 1

\begin{tabular}{|c|c|c|}
\hline & MODIS & SEVIRI \\
\hline Covered period & $2005,2008,2009,2010,2011$ & $\begin{array}{l}\text { March } 2014 \\
\text { November 2016-March } \\
2017\end{array}$ \\
\hline Number of products & 1261 & $\begin{array}{l}148 \text { daily ( } x \approx 50 \text { layers } \\
\text { each day) }\end{array}$ \\
\hline $\begin{array}{l}\text { Frequency of } \\
\text { observation }\end{array}$ & 2 or 3 times per day & every $15 \mathrm{~min}$ \\
\hline Spatial resolution & $250 \mathrm{~m}$ & $3 \times 5 \mathrm{~km}$ \\
\hline $\begin{array}{l}\text { Spectral range of used } \\
\text { band }\end{array}$ & $620-670 \mathrm{~nm}$ & $560-710 \mathrm{~nm}$ \\
\hline
\end{tabular}

A synthetic view of the satellite information used for this study. the two datasets, but to use them as complementary data sources. These types of comparison analyses were already performed for the North Sea area and the results showed a high correlation $\left(r^{2}=0.83\right)$ between the SPM values (and their associated uncertainties) extracted from the two types of satellite information (Neukermans et al., 2009).

Based on satellite SPM maps (with $8 \mathrm{~g} / \mathrm{m}^{3}$ threshold applied for plume definition, as detailed below), two different parameters were computed and further used for different analyses:

- the surface of the turbid plume (in $\mathrm{km}^{2}$ )

- the total mass of sediments - plume mass (in tons), computed within the upper $1 \mathrm{~m}$ water layer (SPM vertical distribution in this first meter was considered homogenous) (Irigoien and Castel, 1997);

Froidefond et al. (1998) showed that the vertical distribution of turbidity within the first meters is often homogenous. In cases where a very well defined surface nepheloid layer is present, the maximum values are reached between 1 and $2 \mathrm{~m}$. Taking into consideration the general values of turbidity found in our AOI, we consider that the optical depth is enough in order to take into account these maximum values under the surface. For brevity reasons, any further references to the plume mass, within this study, should be understood as the SPM mass within the upper $1 \mathrm{~m}$ layer for the plume area delineated as detailed below (using a specific threshold).

\subsection{In situ measurements}

Tidal information was obtained from Port de Bordeaux for the Verdon station (measurements each minute) and from the official site of the Service Hydrographique et Océanographique de la Marine (SHOM), for the Cordouan station (hourly observations). In order to account for the distance between the Verdon station (river mouth) and the plume, a $-30 \mathrm{~min}$ shift in the data series was applied (according to the mean observed time difference between the two stations). These were further used to derive also other types of information, such as the tidal range for each day (computed as the difference between the maximum and minimum water level) or the time for high and low tide moments. Satellite images reflecting high/low tide periods (corresponding to minimum tidal current) were selected using a time window of $1 \mathrm{~h}$ $30 \mathrm{~min}$ before and $1 \mathrm{~h}$ after each event. The rest are considered to belong to either ebb or flood moments. Neap and spring tide periods are defined, for the purpose of this study, as the days when the tidal range is higher, respectively lower than $3.4 \mathrm{~m}$.

River liquid discharge rates for the Gironde were computed as the sum of the Garonne and Dordogne debits measured at Tonneins and Pessac-sur-Dordogne, respectively (Fig. 1). These stations are upstream the area that might be affected by tides, but since the distance from them to the estuary mouth is significant (approximately $100 \mathrm{~km}$ ), a 1 day shift/rectification of the data was performed, based on the average river water speed. The hydrological information was obtained from Banque Hydro service (http://www. hydro.eaufrance.fr/).

Apart from the satellite-derived estimations of SPM, 4 months of continuous (every $15 \mathrm{~min}$ ) autonomous in-situ turbidity measurements were also used. From November 8, 2016 until March 13, 2017, an autonomous bio-optical sensor (Wetlabs ECO-BB2FL) was installed on the GEMMES-20 buoy, located in the proximity of the Gironde mouth (Fig. 1). This buoy is part of the two systems created within the GEMMES (Gironde Estuary Mouth MEaSurements) project, coordinated by IFREMER (L'Institut Français de Recherche pour l'Exploitation de la Mer). The sensor was mounted on the buoy 
at approximately $1 \mathrm{~m}$ below the water surface. Turbidity $(\mathrm{T})$ measurements were translated to SPM concentrations based on the following formula (derived using the results of field campaigns):

$$
\begin{aligned}
\operatorname{SPM}\left(\mathrm{g} \times \mathrm{m}^{-3}\right) & =1.0364 \times \mathrm{T}(\mathrm{FTU}) \quad\left(\mathrm{r}^{2}=0.96,\right. \text { NRMSE } \\
& =6 \%, \mathrm{n}=17)
\end{aligned}
$$

\subsection{Uncertainties associated with the SPM surface plume estimation}

In order to determine the uncertainty associated with SPM surface plume estimations, a two-step process was followed. First, the uncertainty of the algorithms used to transform remote sensing reflectance to SPM values, pixel based (equations (1) and (2)), was computed as Mean Absolute Percentage Error (MAPE). Second step consists in the integration of these pixel based uncertainties over the entire surface, when computing the plume mass. The MAPE was derived using a series of in-situ collected measurements (described above), that were then matched-up with SPM values determined from the satellite information:

$\operatorname{MAPE}(\%)=\frac{100}{\mathrm{n}} \sum_{\mathrm{i}=1}^{\mathrm{n}}\left|\frac{\left(\mathrm{IS}_{\mathrm{i}}-\mathrm{SAT}_{\mathrm{i}}\right)}{\mathrm{IS}_{\mathrm{i}}}\right|$

where $n$, the number of available match-ups, is $n=66$ for MODIS and $n=307$ for SEVIRI; IS $i$ represents the SPM value determined insitu for one moment in time and $S A T_{i}$ the matching satellite estimated SPM concentration. For MODIS, MAPE $=22.5 \%$, while for SEVIRI the value is higher, as expected: $\mathrm{MAPE}=66.3 \%$. One has to take into consideration the fact that match-ups correspond to the winter period, when SEVIRI data is expected to have lower accuracy, due to the low sun zenith angle. Therefore, MAPE might have better (lower) values if summer-time match-ups would be taken into consideration.

For each SPM map (image $A$ ) that was further used to compute the plume characteristics (surface and mass), a random raster (matrix) file (image $B$ ) with the same pixel dimensions, same spatial extent and coordinate reference system was generated. Cells (pixels) were populated with random generated values in the interval $[0.775,1.225]$ for MODIS and [0.337, 1.663] for SEVIRI (according to each MAPE). These random numbers are almost evenly distributed over the entire range (they do not have a normal/ Gaussian distribution). By multiplying each SPM map $(A)$ with the new random grid $(B)$, another probable map of SPM distribution is generated $(C)$. The final step is to use the difference in SPM surface plume mass between $A$ and $C$ in order to compute MAPE, using the same formula listed above (4). Thus the uncertainty associated with the plume characteristics is determined. The results are MAPE $=1.19 \%$ (with $n=60$ ) for MODIS monthly average products and $\mathrm{MAPE}=15.17 \%$ (with $\mathrm{n}=592$ ) for SEVIRI every 15 min images. An important decrease in terms of uncertainty can be observed, which shows how the accuracy of satellite derived data can be significantly increased if the information is integrated over large areas, thus over a large number of pixels.

\section{Results and discussion}

Before any other analysis could be initiated, an apparently simple but crucial issue had to be resolved: where is the outer limit of the sediment plume? Within the Gironde plume area, several distinct regions can be found, in respect to SPM variations. First, a coastal area can be identified, where SPM values are high almost all year long and that can stretch north up to the Loire estuary (Hermida et al., 1998). Second, a wider area which is dominated by SPM brought by the Gironde and from the area of Marennes-Oleron (Lafon, 2009). Last, the region of the Gironde plume itself. Since the present study aims at analyzing the third region alone, delineation had to be made between this and the wider second area. This was performed by applying a simple SPM threshold when delineating the plume extent on satellite images. Previous studies established the limit between the "clear" and "turbid" waters at 3 FTU (Formazin Turbidity Units) (Castaing et al., 1999), while later ones (Lafon, 2009) have argued that the plume limit can be found between 6 and $10 \mathrm{~g} / \mathrm{m}^{3}$. Since we require that the number of pixels going into further computation should be as high as possible (therefore, a wider area classified as "plume" would be preferred), two distinct scenarios were tested using MODIS imagery: the limit of the plume drawn at $6 \mathrm{~g} / \mathrm{m}^{3}$ and at $8 \mathrm{~g} / \mathrm{m}^{3}$ (results not shown here). It was observed that for multiple situations, when the plume extent is medium to high, using the $6 \mathrm{~g} / \mathrm{m}^{3}$ threshold leads to cases when the northern part of the plume is merged with the one coming from the northern Marennes-Oleron region and extends well beyond our AOI. By applying the $8 \mathrm{~g} / \mathrm{m}^{3}$ limit, this effect is reduced and the observed plume is more likely to be only related to Gironde outputs. Also, Petus et al. (2010) showed that the red MODIS band has a moderate sensibility for variations between 4 and $8 \mathrm{~g} / \mathrm{m}^{3}$. The uncertainties associated with the atmospheric correction procedure are higher with decreasing remote sensing reflectance values, thus for lower SPM concentrations, the errors can become significant (Ruddick et al., 2000; Goyens et al., 2013). Therefore, the second option - a fixed threshold of $8 \mathrm{~g} / \mathrm{m}^{3}$ for plume delineation, was finally chosen for the present study, both for MODIS and SEVIRI data.

\subsection{River discharge effect on seasonal SPM plume dynamics (as observed using MODIS)}

Earlier studies (Froidefond et al., 1998) found some incipient evidence regarding the seasonal variations of the SPM plume, with lower extensions during the summer and the highest ones during the winter and spring periods. In terms of plume dynamics in correlation with the river discharge rates, their results were not conclusive (no overall evident relationship found), either due to the low number of images considered, either due to the coarser spatial resolution used ( 1 pixel $=1 \mathrm{~km}^{2}$, compared to the present study where 1 pixel $=0.0625 \mathrm{~km}^{2}$ ).

As previously mentioned, the five years of processed MODIS data (2005 and from 2008 to 2011) reflect all possible river discharge conditions. Years 2005, 2011 have the lowest overall discharge rates (534 and $469 \mathrm{~m}^{3} / \mathrm{s}$ respectively), with maximum daily values barely exceeding $1000 \mathrm{~m}^{3} / \mathrm{s}$ for short periods of time. In contrast, year 2008 is on the other extreme $\left(882 \mathrm{~m}^{3} / \mathrm{s}\right.$ annual average), with monthly values from March to May well above the multi-annual monthly curve. Although, overall, the discharge average is lower in $2009\left(741 \mathrm{~m}^{3} / \mathrm{s}\right)$, compared to 2008 , the highest daily debits were recorded during January 2009, when the combined debits of Garonne and Dordogne exceeded $6000 \mathrm{~m}^{3} / \mathrm{s}$. Year 2010 is a moderate one in terms of river discharge, with monthly values very close to the multi-annual average and with several periods when the debit peaks are between 1000 and $2000 \mathrm{~m}^{3} / \mathrm{s}$.

Seasonal variations of the plume dynamics were analyzed based on average composite products corresponding to 6 time periods of two months over the year (Fig. 2). The largest extension corresponds to the highest river discharge rates (January-February). The offshore limit of the plume can be found well beyond $30 \mathrm{~km}$ from 
the coastline, with a tendency towards the northern direction. From March to April, since the river discharge continues to be high, but in a decreasing trend, the SPM mass in front of the Gironde mouth is still increased. The following three periods (from May to October) are characterized by low sediment outflows, which can be noticed also on the maps in Fig. 2. During summer, a smaller secondary plume, coming from the Marennes-Oleron area (which includes the Charente River mouth), can be distinguished. This can be observed only during these specific conditions (low river discharge), coming to reinforce the idea that the discrimination between the two main sources of SPM in the area is difficult, since most of the time the two plumes are merged. Finally, the last period of the year, November-December, when the river input increases again, the overall SPM plume becomes more extended, but also more elongated in a north-south direction and closer to the shoreline. The overall limit does not exceed a distance of $25 \mathrm{~km}$ offshore. The number of usable images $(\mathrm{N})$ for each seasonal period is a good indicator of the general nebulosity and it shows how good quality scenes are distributed over the year. In terms of monthly correlation between the plume mass and the river discharge rates (Fig. 2, bottom graphic), there is a general good agreement. It can be observed that the maximum SPM output tends to occur slightly before the maximum liquid discharge. Also, during longer periods with high river water outflows or when the river discharge drops and then comes back again to high values, the overall SPM mass does not follow the same trend, but stays at low levels. This is probably due to the fact that during these periods the river tends to become depleted of suspended sediments that are usually brought inside the estuary at the beginning of flood events (maximum erosion rates) and then spread over the continental shelf. Moreover, on top of this natural behavior of the river, the MTZ formed inside the estuary plays also an important role. During the beginning of flood periods, the MTZ can be partly pushed outside the estuary, resulting in very high SPM concentrations in the shelf area and a more extended plume. At annual level, years with higher river discharge correspond to periods with increased plume mass.
Both surface and mass of the plume show an overall good correlation with the river discharge rate $\left(R^{2}=0.98\right.$ for surface and $\mathrm{R}^{2}=0.96$ for mass, respectively; where $\mathrm{R}^{2}$ is the coefficient of determination) (Fig. 3). For minimum river debits (up to $300 \mathrm{~m}^{3} / \mathrm{s}$ ), there is no clear correlation between these parameters (even a slight decrease is noticeable). From 300 to $1000 \mathrm{~m}^{3} / \mathrm{s}$, a continuous and steady increase can be observed. For the last two categories, a tendency of saturation is visible, specifically concerning the plume mass. This is related either to the above mentioned river's tendency to reduce the amount of carried suspended sediments after specific thresholds and/or to the decreasing availability of sediments in the downstream part of the estuary at the end of a flood event. This overall linear relationship is, however, valid on large time scales, since the effect of tidal regime and other forcing factors is diluted, due to their cyclic and higher temporal variability. This is similar to the seasonal dynamics analysis, where only the river runoff has significant periodical variations, out of the major controlling factors for the SPM plume.

\subsection{Combined effect of river discharge and tide regime on SPM dynamics (as observed using MODIS)}

While at seasonal and monthly scales the river discharge is the most influential factor determining the SPM plume dynamics, daily and hourly changes are mostly controlled by the tidal conditions. In order to analyze how this affects the overall distribution of the SPM plume, all MODIS images were placed into 8 different categories, each corresponding to distinct environmental conditions (Fig. 4). The high and low tide periods were computed using a time window (specified in the methodology section) around the maximum/ minimum water level (high tide/low tide). Distinction between neap and spring tides was done by using the $3.4 \mathrm{~m}$ threshold for the daily water level range.

One of the first observations to be made is the limited number of cases identified for high/spring tides, due to the orbit patterns of MODIS that rarely superimpose these conditions. Nonetheless,
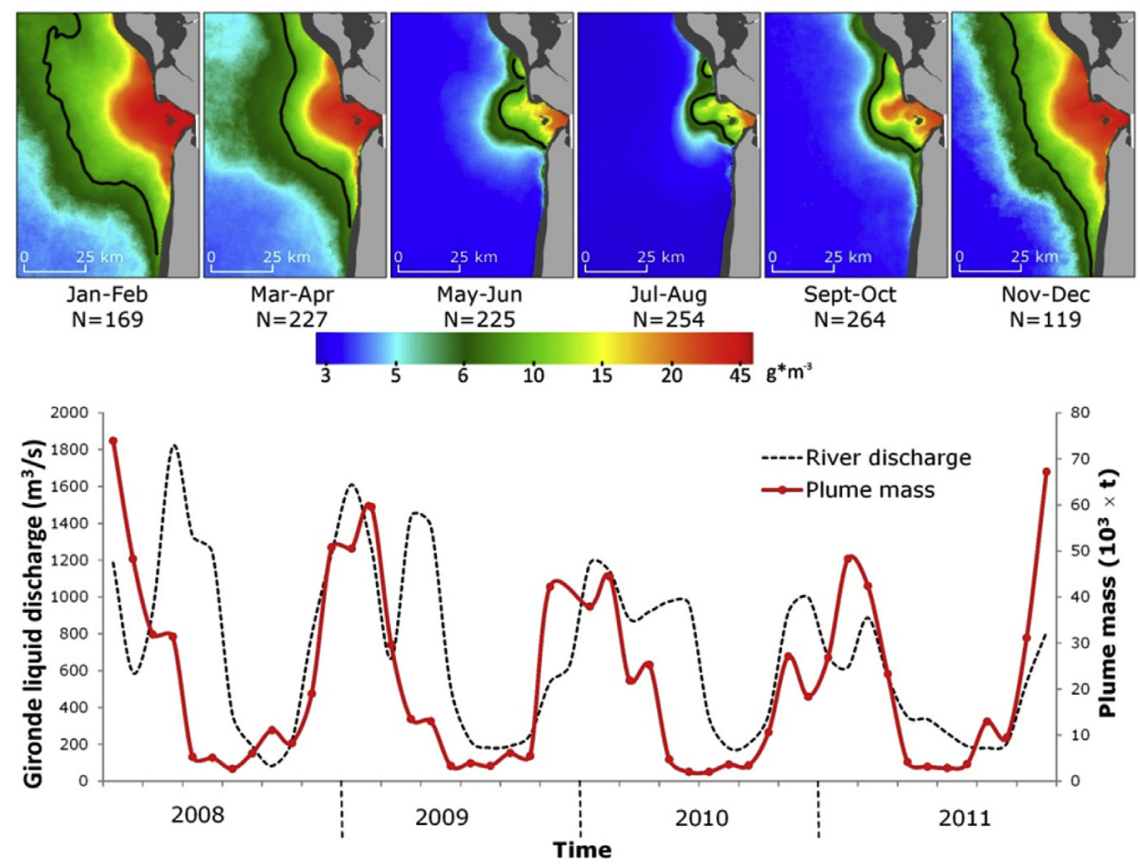

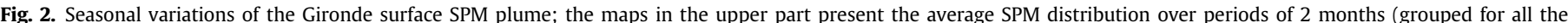

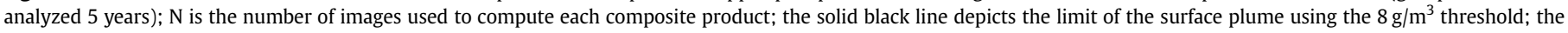
bottom graphic shows the evolution of the monthly SPM surface plume mass over the 2008-2011 period in correlation with the river discharge. 

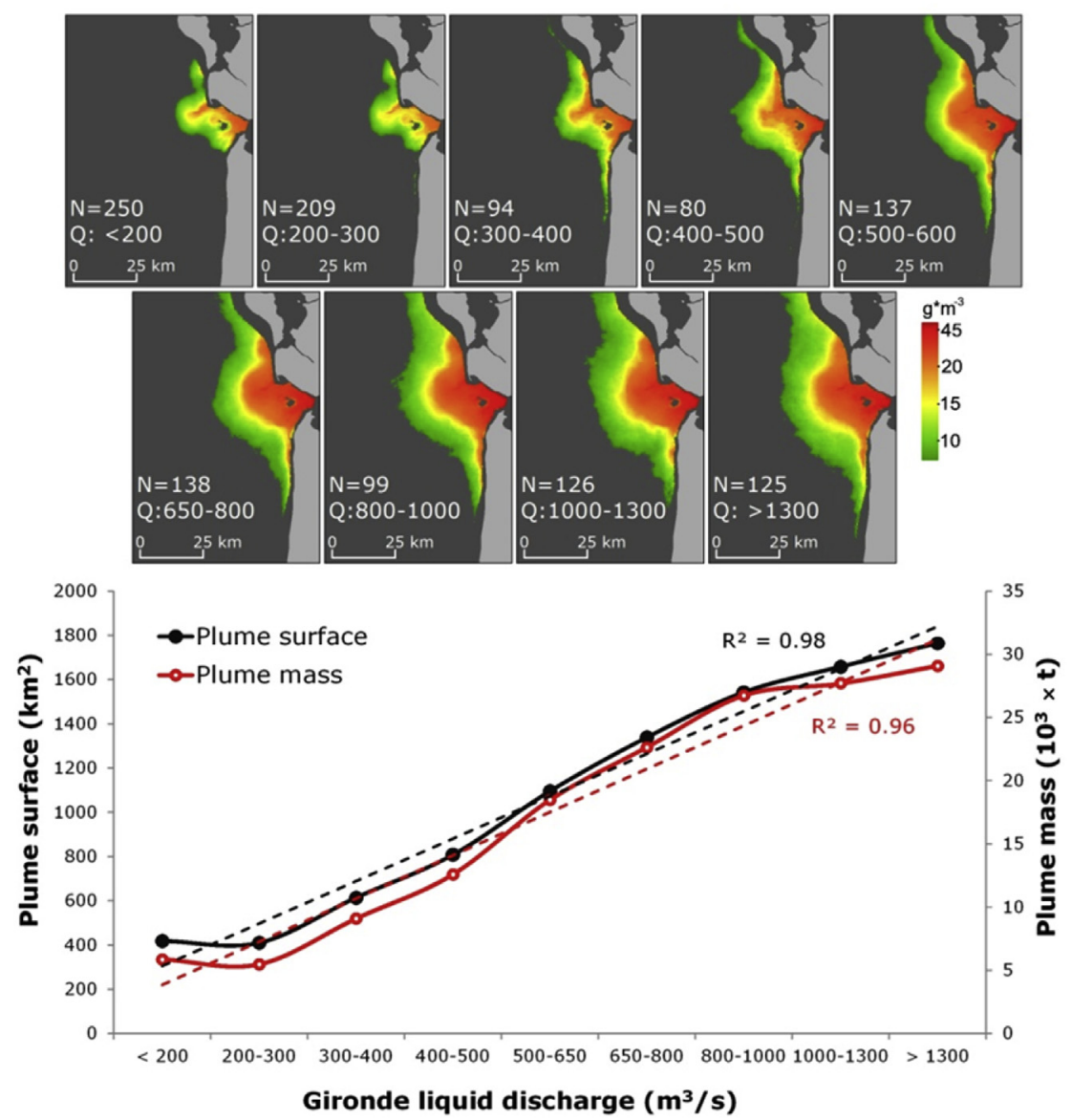

Fig. 3. SPM surface plume extension according to different categories of river discharge rates; $\mathrm{N}$ is the number of images used to compute each composite product; $\mathrm{Q}$ represents the river discharge in $\mathrm{m}^{3} / \mathrm{s}$.

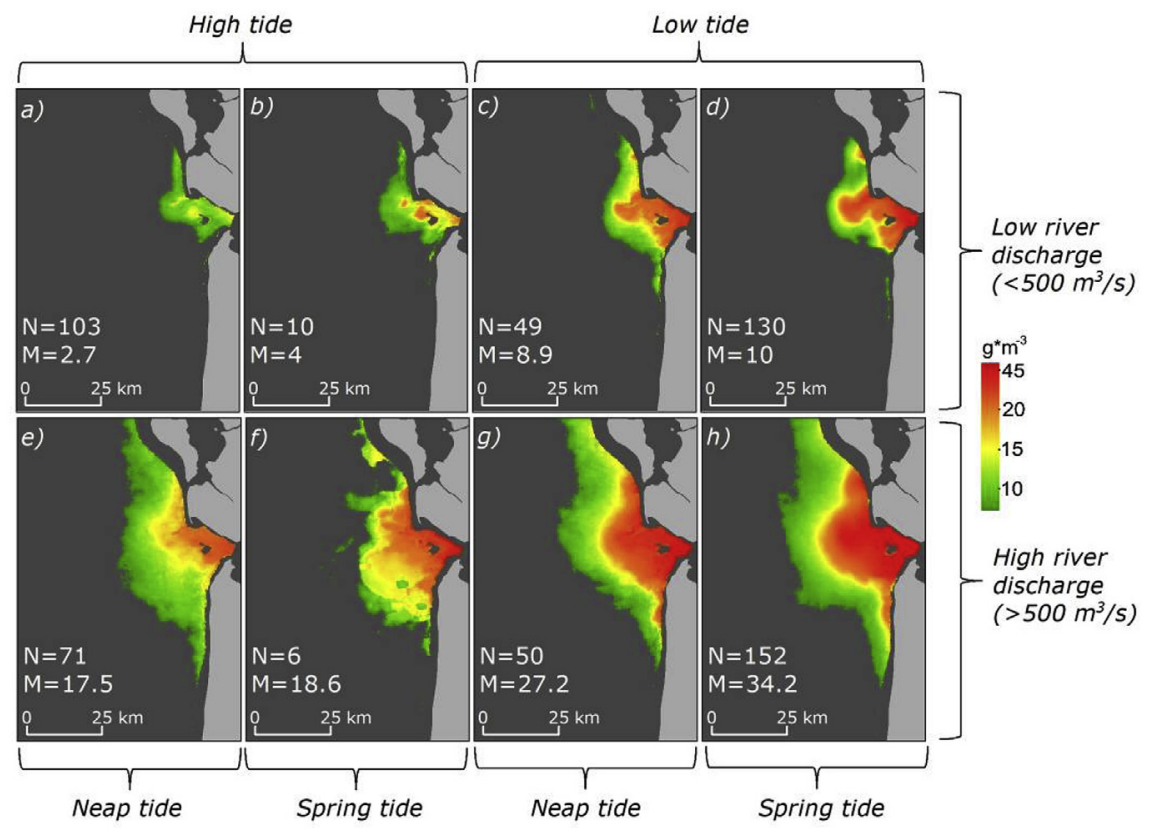

Fig. 4. SPM surface plume extension for multiple environmental conditions; $\mathrm{N}$ is the number of images used to compute each composite product; $\mathrm{M}$ represents the mass of the plume in $10^{3} \times \mathrm{t}$ 
thanks to the long time series of satellite data used for the study, 16 images were identified and further used (Fig. 4, classes $b$ and $f$ ). Therefore, conclusions for these particular cases are not solid enough and need to be treated with care.

Overall, the river discharge rates still play an important role, but differences are to be noticed according to tidal conditions. Low tide periods exhibit almost a $100 \%$ increase in SPM mass, compared to high tide. Another increase, at a smaller scale, was also observed between neap and spring tides. The lowest plume extension and consequently lowest SPM concentrations are to be observed, as expected, during low river discharge/high tide/neap tide conditions (Fig. 4, class $a$ ). In such cases, SPM values at the river mouth do not exceed $15 \mathrm{~g} / \mathrm{m}^{3}$ on average.

For class $f$, an abrupt change can be noticed in SPM concentrations. The outer limit of the plume has a very steep gradient. This may be caused by the fact that, while the rivers bring large amounts of suspended sediments which are rapidly transported throughout the estuary, the plume is pushed towards the shoreline by tidal currents. This determines the compressed shape of the plume, with a steep SPM gradient for the plume offshore limit. But, the results shown by class $f$ and $b$ are to be considered just a hypothesis for the time being, due to the limited number of images covering these conditions. Other satellite sensors, or in-situ measurements, which overlap the spring - neap tide conditions would be required in order to confirm these observations. At the same time, for similar tidal conditions and river discharge, but during neap tides (class $e$ ), flood currents are not strong enough to push the plume eastwards therefore it has a relatively high extension $-1385 \mathrm{~km}^{2}$ (higher than for $f$ case: $1096 \mathrm{~km}^{2}$ ). Dilution in the coastal waters is also very evident compared to low tide moments, therefore the concentrations are lower (barely reaches $25 \mathrm{~g} / \mathrm{m}^{3}$ near the mouth) and so is the mass $\left(17.510^{3} \times \mathrm{t}\right)$. The visual inspection of the maps does not reveal any important difference for low tide conditions and high river discharge ( $g$ and $h$ ). Nevertheless, the extent of the plume is $18 \%$ higher during spring tides $(h)$ compared to neap tides $(g)$. The increase is even more consistent in terms of mass of SPM $(+26 \%)$. For class $h$, the average SPM values near the mouth are between 45 and $50 \mathrm{~g} / \mathrm{m}^{3}$.

During low tide and high river discharge, the large extension of the plume is caused, apart from the high SPM concentration inside the estuary, by the combined effect of the tidal and fluvial currents. Higher extension of the sediment plume during ebb tide conditions is not only a direct effect of particles being flushed out of the estuary. An important role might be played also by the saltier, thus denser, oceanic waters that act like a barrier blocking the less salty waters close to the shoreline (Castaing et al., 1999). The ebb tidal currents can push this oceanic mass of water further offshore, leaving enough space for the fluvial waters to spread over the continental shelf.

All MODIS scenes available for this study were also split into four different categories depending on the prevailing wind direction. The results were not consistent enough and did not show any particular trend, most probably due to the high dynamics of the wind patterns at short time scales (Hermida et al., 1998). However, a much larger extension of the plume was observed when the wind had an eastern direction, compared to the other situations. The dynamics of the SPM plume as a direct consequence of wind effects is a complex topic that would require more in-depth investigations, outside the scope of this current study.

\subsection{Daily SPM plume variations}

\subsubsection{Daily cycles observed using MODIS}

Previous studies (Froidefond et al., 1998; Lafon, 2009) have shown the important role played by flood and ebb currents in the daily dynamics of the SPM plume. However, these studies did not account for all the four different moments imposed by the tidal regime. Since MODIS sensors can offer two or even three images per day of the AOI (depending on cloud cover), with a gap between the two acquisitions of roughly $2 \mathrm{~h}$ (can be higher if more than two passes are recorded), a complete theoretical (synthetic) daily tidal cycle could be observed. In Fig. 5, a selection of MODIS Terra and Aqua pairs were plotted as to show the difference in SPM concentrations between them (increase in orange-red colors and decrease in blue shades). The pairs of images come from different days, so they reflect different river discharge conditions. Therefore the maps should not be interpreted in terms of magnitude of differences. Instead, they show very well the overall tendencies in correlation with the daily tide water levels. The bottom graphic contains the positions of these MODIS images relative to high and low tide (relative positions, since the pairs come from different days).

What can be observed from these synthetic daily SPM variation maps is that the extension of the turbid plume starts growing during ebb tide, when the waters from inside the estuary are forced out by the currents, and peaks its maximum during the low tide. Right at the onset of the ebb period (after the highest water level value) the plume dynamics are not that significant (Fig. 5 a). The gradient of variation is larger during the following period (from the beginning of the ebb until low water levels), since the fluvial waters are forced out from the estuary. In such conditions, the SPM concentrations can increase by more than $10 \mathrm{~g} / \mathrm{m}^{3}$ (Fig. $5 \mathrm{~b}$ and $\mathrm{c}$ and $\mathrm{d}$ ). The accretion of the turbid plume stops once the tidal currents attenuate and the processes alternates between increasing and decreasing SPM (Fig. 5 e). During the flood, the dilution imposed by the offshore waters makes the SPM values drop, with more than $10 \mathrm{~g} / \mathrm{m}^{3}$ in specific conditions (Fig. $5 \mathrm{~g}$ ). Also, the fluvial waters are trapped within the estuary, so the SPM remains stable toward the end of the flood moment (Fig. 5 h), at relatively low values. In case of low or medium river discharge situations, the plume can completely fade away during high tide.

\subsubsection{Daily cycle observed using SEVIRI satellite data}

While MODIS satellite proved to be useful and adapted to monitor the variations of the SPM plume between two moments each day and even reconstruct a synthetic overview of an entire daily cycle, the SEVIRI sensor offers the capability to do the same analysis each day (during approximately $6-7 \mathrm{~h}$, depending on illumination conditions). The time gap between images is $15 \mathrm{~min}$, providing there is no cloud cover. Despite the low spatial and spectral resolution, SEVIRI can capture the evolution of the SPM plume with enough detail required for further analysis (e.g., see on Fig. 6 SEVIRI-derived SPM maps produced every 30 min from 8:00 to 13:30 on March 10, 2017; the time gap between each successive image was cut to $30 \mathrm{~min}$, instead of available $15 \mathrm{~min}$, to augment the dynamics). The maps in Fig. 6 correspond to a very high river discharge $\left(2508 \mathrm{~m}^{3} / \mathrm{s}\right)$ and a tidal range of $3.7 \mathrm{~m}$. It can be observed how the SPM concentrations are decreasing during this time period, with a reduction in SPM values above $-10 \mathrm{~g} / \mathrm{m}^{3}$ in the river plume.

The in-situ turbidity data recorded between November 2016 and March 2017 at the mouth of the estuary allowed re-analyzing and reconfirming the relationship between water turbidity and tidal conditions (Fig. 7). During spring tides and high river discharge conditions, the correlation between the two parameters is evident (Fig. 7 d; maximum values of SPM are reached during such periods: up to $80-90 \mathrm{~g} / \mathrm{m}^{3}$, in this particular case). It is less obvious during neap tides (Fig. $7 \mathrm{~b}$ and $\mathrm{c}$ ). During medium tidal range and high river discharge (Fig. $7 \mathrm{c}$ ), although the fluvial debit is higher than in case a), the SPM variations are similar. This is due to the fact that tides play a more important role in SPM dynamics 

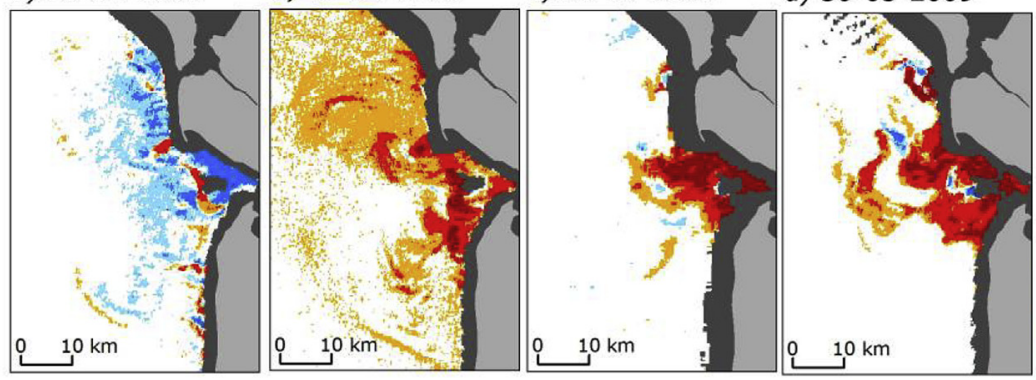

SPM change from

Terra to Aqua

$\left(g^{*} \mathrm{~m}^{-3}\right)$

e) $29-08-2010$

f) $18-10-2009$

g) 10-01-2009

h) $22-04-2009$
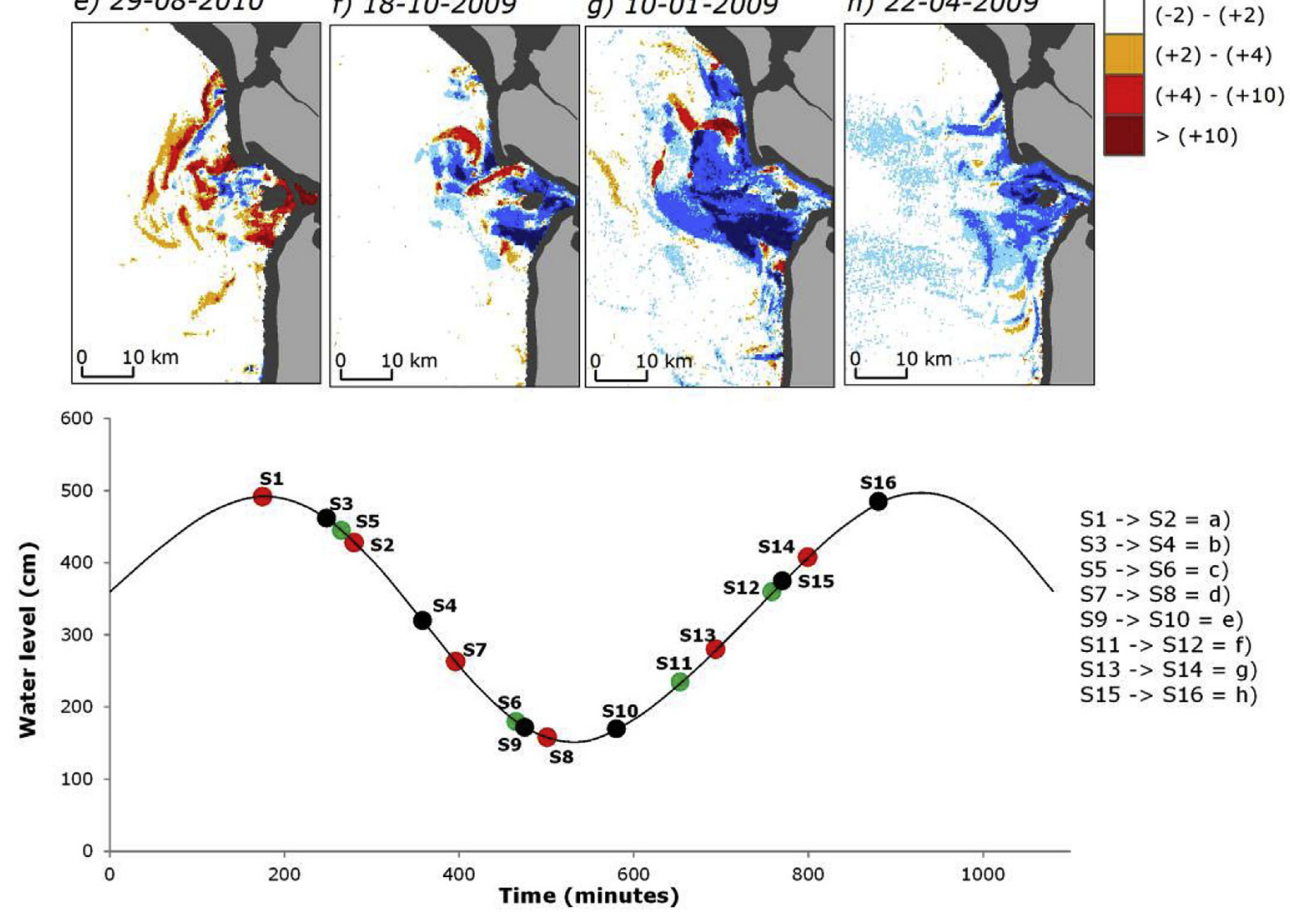

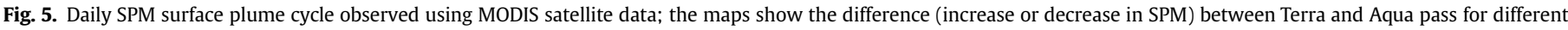

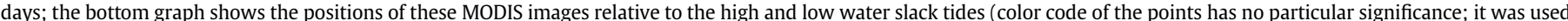

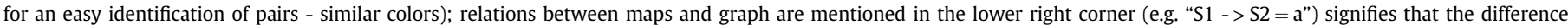

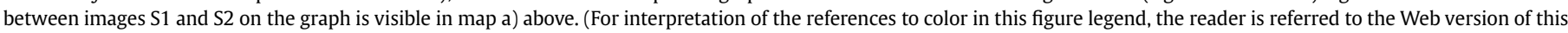
article.)

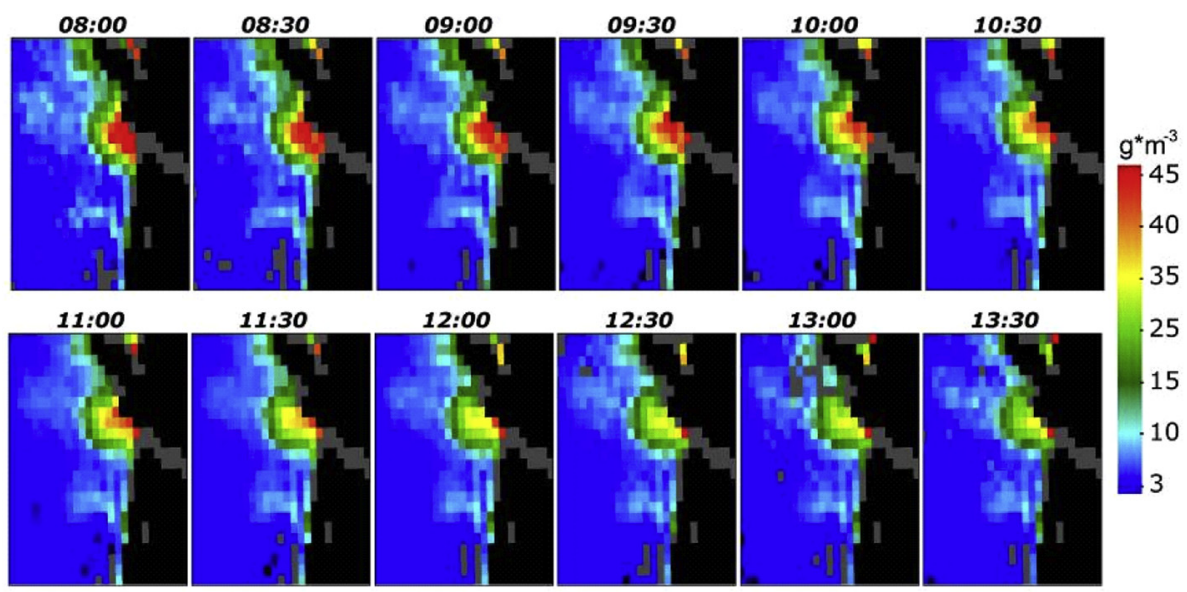

Fig. 6. SPM maps obtained from SEVIRI information for March 10, 2017. 


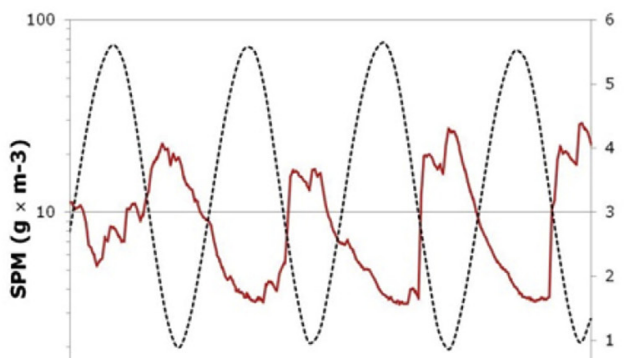

a) 14-15 Dec. 2016

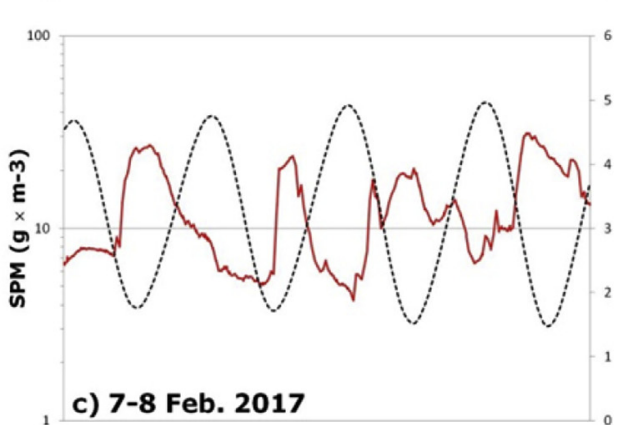

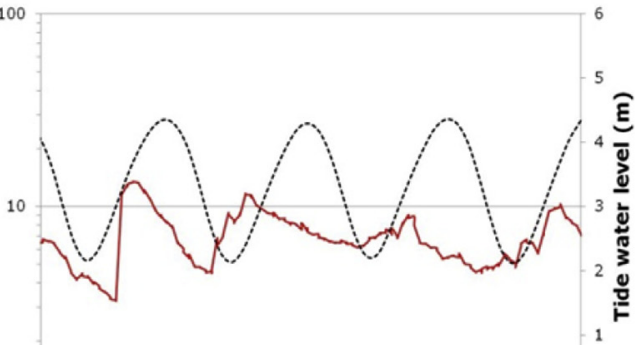

b) 22-23 Dec. 2016

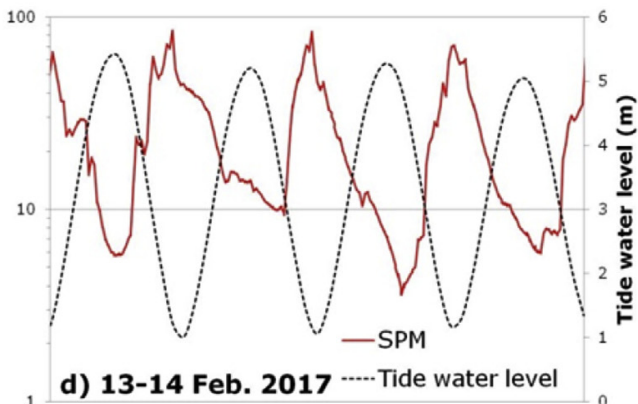

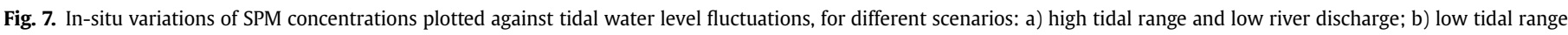
and low river discharge; c) medium tidal range and high river discharge; d) high tidal range and high river discharge.

compared to river outputs. Also, patterns of sediment sinking are well visible during the minimum water levels, when the tidal current is at its minimum.

Thus, it is expected that by using SEVIRI information, the same rules will apply, meaning that consistent results are to be expected only for specific environmental conditions. Therefore, the objective is to retrieve similar patterns using SEVIRI data, despite the rather low sensitivity of the sensor (inferior to the in-situ instrument) and its low spatial resolution.

A good inverse relationship is observed between SPM plume metrics (mass and surface) estimated using SEVIRI data and the water level variations over daily tidal cycles (Fig. 8). Out of a total of 148 daily products that were analyzed within this study, clear patterns of SPM variations were identified only in 19 situations ( 9 of which are presented in Fig. 8). The main causes for the limited number of good observation cases are cloud cover (partial of complete occultation of the plume), low sun zenith angle and low SPM values (difficult to account for due to low sensor sensitivity in such conditions). It can be noticed that most of the cases correspond to high river discharge and moderate to high tidal range conditions. All of these examples show a clear decrease in both mass and surface of the plume during the flood periods, meaning from low to high water levels. During ebb, the inverse situation is observed, with important increases of SPM (Fig. 8 a, $\mathrm{f}$ and g). The most extended plume (more than $4500 \mathrm{~km}^{2}$ in surface and up to $80 \mathrm{t} \times 10^{3}$ in mass) was identified on February 11,2017 , when both the river outflow $\left(1426 \mathrm{~m}^{3} / \mathrm{s}\right)$ and the tidal range $(4.6 \mathrm{~m})$ were very high. This is also the event with the smoothest transition from one moment to another (every $15 \mathrm{~min}$ ), since the high SPM concentrations accounted better for the low sensitivity of the satellite sensor. The same small drop in SPM concentration at low water that was identified using the in-situ data mentioned before is detected on satellite data as well. This trough (depression) in SPM evolution is related to the minimum speed of the currents (close to zero), and certainly correspond to the settling of SPM at the reverse of tidal currents (Fig. 8 c, f and i).

Results for the Gironde plume area are in line with previous studies using SEVIRI data (Neukermans et al., 2009, 2012; Ruddick et al., 2013) that focused on the North Sea area and which showed the capabilities of the geostationary satellite sensor to detect diurnal cycles of SPM, turbidity and attenuation of photosynthetically available radiation ( $K_{\text {PAR }}$, in $1 / \mathrm{m}$ ). Compared to the North Sea, the viewing angle of the satellite is smaller over the Gironde area. Therefore, the obtained products are expected to be more consistent overall. Also, delineation of the plume at $8 \mathrm{~g} / \mathrm{m}^{3}$ reduces considerably the uncertainties of retrieving SPM, mainly associated with clear waters (Neukermans et al., 2009). The limit for "clear waters" in terms of SEVIRI sensitivity was considered to be at approximately 10 FTU (Vanhellemont et al., 2014). The threshold used for this study might incorporate also a very limited number of pixels from this category. But, since all of them are aggregate and the plume is considered as a whole, their effect if negligible. Compared to other studies using GOCI data (He et al., 2013; Choi et al., 2014; Cheng et al., 2016; Eom et al., 2016), the same type of results were obtained also using SEVIRI for the Girone area. Nevertheless, thanks to its better spatial and spectral capabilities, GOCI has the potential to resolve more fine patterns of SPM dynamics and can perform better in clear waters. The Yalu River macro-tidal estuary is a good example of a similar area (compared to Gironde) analyzed based on GOCI data (Cheng et al., 2016). Nevertheless, the forcing factors of SPM dynamics are different, with wind stress playing a more important role. Hourly to seasonal variations could be very well observed.

In terms of validation aspects, it was previously shown that water quality information derived from SEVIRI data are well correlated with the ones estimated using MODIS satellite information (Neukermans et al., 2012). The same relationship was found also in terms of uncertainties associated to these estimations as well, with higher uncertainties in clear waters for SEVIRI. Validation activities were carried out also based on in-situ data (collected by the SmartBuoys network), pixel by pixel. For turbidity, a good correlation was observed between the two parameters $\left(R^{2}=0.933 \pm 0.006\right)$ (Neukermans et al., 2012). On average, turbidity, which is a robust proxy for SPM, is underestimated by 

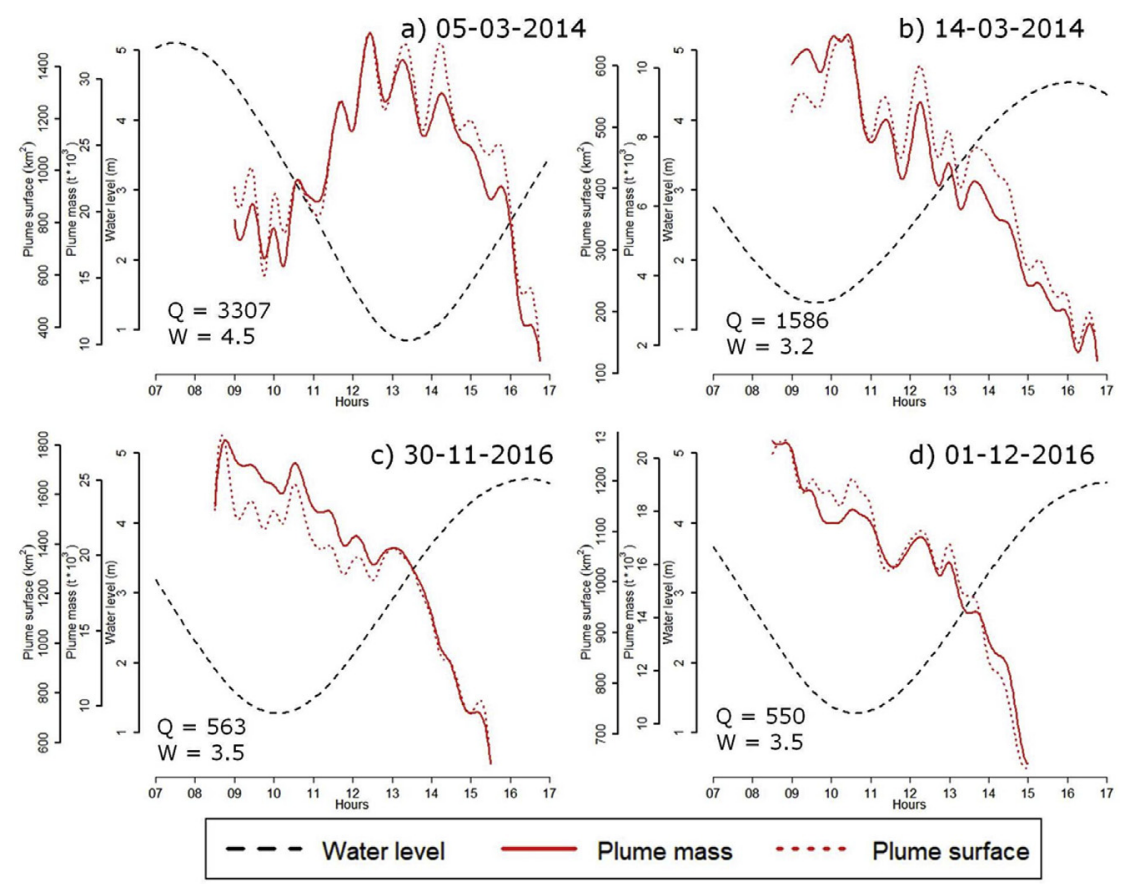

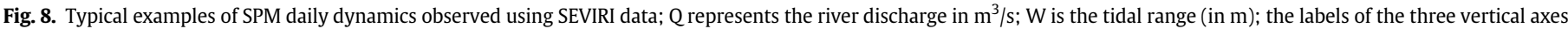
are, from left to right: plume surface $\left(\mathrm{km}^{2}\right)$, plume mass $\left(\mathrm{t}^{*} 10^{3}\right)$ and water level $(\mathrm{m})$.

SEVIRI by $14 \%$, with a median prediction error of $29 \%$ (Neukermans et al., 2012). The quality of the estimations can be improved by applying data fusion techniques with MODIS data, especially in clear waters (Vanhellemont et al., 2014). For the Gironde area, the well defined inverse relationships visible in Fig. 8 and the similarity with the results obtained using in-situ recorded data (Fig. 7) are a confirmation of the fact that SEVIRI information can be successfully used to estimate the diurnal variability of the SPM plume. Furthermore, the SEVIRI data used in this study covers periods with low sun angles (winter to spring), therefore conditions under which the quality of the derived SPM information is expected to be lower (Neukermans et al., 2009) compared to high sun angle intervals. Therefore, since worst case conditions (in terms of sun angle) proved not to be a challenge, it is expected that the results will have at least the same quality for the rest of the year.

\section{Conclusions}

By taking full advantage of the long archive of satellite imagery acquired by the MODIS sensors at a spatial resolution of $250 \mathrm{~m}$, new insights regarding highly dynamic coastal waters directly influenced by river discharges can be gained. In this study, the average seasonal extension of the SPM plume at the mouth of the macrotidal Gironde estuary was determined. At monthly scale, although there is an obvious dependency between the river discharge and SPM plume (extent and mass), the correlation between the two is not perfect, mainly because of the minor shift between maximum levels of liquid and solid discharge rates. However, globally, over the entire analyzed period, a linear relationship can be deducted between different classes of river outflow rates and SPM concentration in the adjacent coastal area. While initial studies (Hermida et al., 1998) concluded that the tidal dynamics plays a minor role in the transport of fluvial inputs over the continental shelf, we show within our study that it is probably the most important factor governing the SPM distribution, not only at short time scales, but also overall. Daily plume dynamics can be monitored using MODIS derived information, in a synthetic manner, but this requires indepth searches for images pair that can satisfy multiple conditions in terms of water level fluctuations. For such endeavors, satellites with increased revisit capability would be necessary.

For the first time we also captured the daily dynamics of the Gironde SPM plume using geostationary satellite data. We showed that this dynamic is closely related to the daily tidal cycle, with a SPM plume extent maximum at low water and minimum at high water and typical variations by a factor 2 in terms of mass and extent during spring tide conditions. While SEVIRI has proven to be useful for SPM plume dynamics monitoring at high temporal scales, its limits, mainly in terms of spectral and radiometric performances and environmental conditions under which it performs well, need to be properly accounted for. With only $13 \%$ ( 19 good cases out of a total of 148 analyzed) success rate, in our situation, it is clear that SEVIRI can be used just for specific moments. The causes are multiple and each has a different impact on the overall quality of such an investigation. Most important is the cloud cover. The sun zenith angle plays as well an important role. Local conditions need also to be accounted for, since during low river discharge and neap tides (thus low SPM values) it becomes more difficult to retrieve consistent information. This is because SEVIRI has the tendency to under-estimate the SPM concentration for low turbid waters with approximately $15 \%$ on average and up to maximum $50 \%$ (Vanhellemont et al., 2014; Ody et al., 2016). Most of the previously identified causes for differences between SEVIRI and ground-truth data (in-situ measurements) (Neukermans et al., 2012) are mitigated by using the approach described in the present study (computation of SPM mass within the surface plume, which integrates both information regarding plume extent and SPM concentrations), instead of relying just on single pixel analysis or just mean SPM concentration over an area. This assures the identification of patterns otherwise not distinguishable. Nonetheless, there is an obvious need for future geostationary sensors with improved 

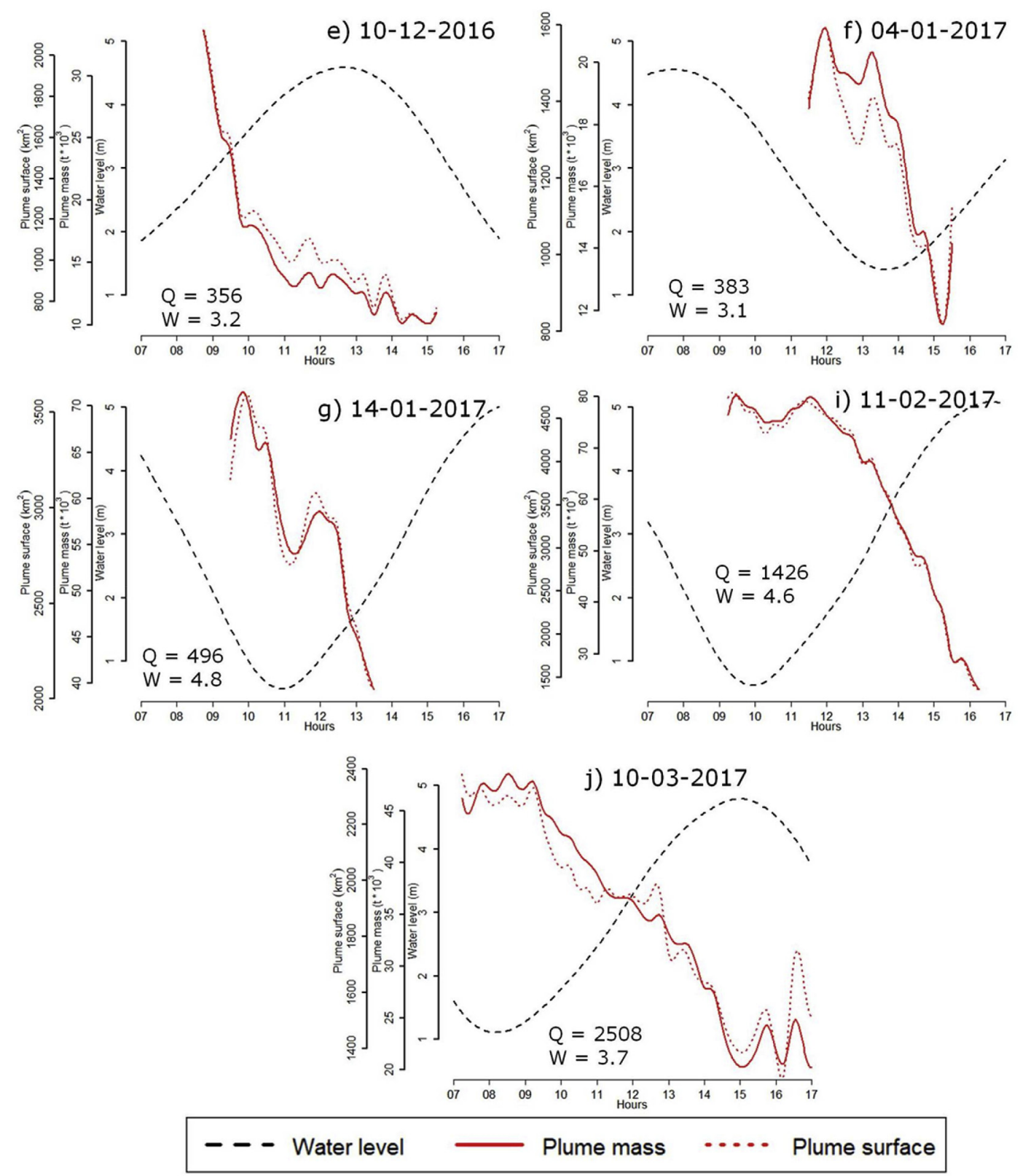

Fig. 8. (continued).

capabilities, as it was shown as well by other studies using geostationary data (He et al., 2013; Choi et al., 2014; Cheng et al., 2016; Eom et al., 2016), that such information can be very useful for coastal applications. Only through such technological advances, dynamic areas, such as the Gironde river mouth, will be properly monitored.

Overall, the study shows how, by using different types of satellite data, sediment plume dynamics can be analyzed at multiple time scales. Using MODIS data (two, up to three images per day), the seasonal and other long term patterns were observed and the major role played by the river output was reinforced and even parameterized. Relevant information on the daily dynamics of the plume was also retrieved using MODIS data. The daily dynamic of the plume (in terms of plume extent and SPM mass, which were proved to vary by a factor 2 during spring tides) was very well captured using geostationary (SEVIRI) satellite data and analyzed in more in-depth in relation with daily tidal cycles.
One obvious perspective is to combine the use of geostationary data and long-term ocean color satellite observations for the calibration and validation of sediment transport models over large time scales (from daily to seasonal and even multi-annual time scales) (e.g. El Serafy et al., 2011; Sottolichio et al., 2014; Gangloff et al., 2017; Yang et al., 2016). This will certainly help improving the realism of models, better understand the physical and chemical processes involved in SPM transport and estimate the SPM discharge rates at the land-ocean interfaces.

\section{Acknowledgements}

This work was funded by the European Community's Seventh Framework Programme (FP7/2007-2013) under grant agreement no. 606797 (HIGHROC project, www.highroc.eu).

In-situ data was collected with the help of L'Institut Français de Recherche pour l'Exploitation de la Mer (IFREMER). MODIS satellite 
data was acquired from NASA Ocean Biology (OB.DAAC). EUMETSAT and the Royal Meteorological Institute of Belgium are acknowledged for providing SEVIRI data. The authors want to thank Alexandra Coynel (Univ. Bordeaux, France) for providing tidal data (collected by the Port de Bordeaux) and Quinten Vanhellemont for developing the algorithm used to process SEVIRI information up to Level 2. We would like to thank also the three anonymous reviewers, Kevin Ruddick and Marco Bellacicco for their very useful comments and suggestions.

\section{References}

Agence de l'Eau Adour Garonne, 1994. Synthèse des connaissances de l'estuaire de la Gironde. Bordeaux. Available online at: http://archimer.ifremer.fr/doc/00106/ 21708/19287.pdf.

Castaing, P., Froidefond, J.-M., Lazure, P., Weber, O., Prud'Homme, R., Jouanneau, J.M., 1999. Relationship between hydrology and seasonal distribution of suspended sediments on the continental shelf of the Bay of Biscay. Deep. Res. Part II 46, 1979-2001. https://doi.org/10.1111/j.1467-8330.1974.tb00606.x.

Constantin, S., Constantinescu, S., Doxaran, D., 2017. Long-term analysis of turbidity patterns in Danube Delta coastal area based on MODIS satellite data. J. Mar. Syst. 170, 10-21. https://doi.org/10.1016/j.jmarsys.2017.01.016.

Cheng, Z., Wang, X.H., Paull, D., Gao, J., 2016. Application of the Geostationary Ocean Color Imager to mapping the diurnal and seasonal variability of surface suspended matter in a macro-tidal estuary. Rem. Sens. 8. https://doi.org/10.3390/ rs8030244.

Choi, J.-K., Park, Y.J., Lee, B.R., Eom, J., Moon, J.-E., Ryu, J.-H., 2014. Application of the Geostationary Ocean Color Imager (GOCI) to mapping the temporal dynamics of coastal water turbidity. Remote Sens. Environ. 146, 24-35. https://doi.org/ 10.1002/2014JC009981.

Dogliotti, A.I., Ruddick, K.G., Nechad, B., Doxaran, D., Knaeps, E., 2015. A single algorithm to retrieve turbidity from remotely-sensed data in all coastal and estuarine waters. Remote Sens. Environ. 156, 157-168. https://doi.org/10.1016/ j.rse.2014.09.020.

Dogliotti, A.I., Ruddick, K., Guerrero, R., 2016. Seasonal and inter-annual turbidity variability in the Río de la Plata from 15 years of MODIS: El Nino dilution effect. Estuar. Coast Shelf Sci. 182, 27-39. https://doi.org/10.1016/j.ecss.2016.09.013.

Dorji, P., Fearns, P., 2016. A quantitative comparison of total suspended sediment algorithms: a case study of the last decade for MODIS and landsat-based sensors. Rem. Sens. 8. https://doi.org/10.3390/rs8100810.

Doxaran, D., Froidefond, J.-M., Lavender, S., Castaing, P., 2002. Spectral signature of highly turbid waters. Application with SPOT data to quantify suspended particulate matter concentrations. Remote Sens. Environ. 81, 149-161.

Doxaran, D., Froidefond, J.M., Castaing, P., Babin, M., 2009. Dynamics of the turbidity maximum zone in a macrotidal estuary (the Gironde, France): observations from field and MODIS satellite data. Estuar. Coast Shelf Sci. 81, 321-332. https:// doi.org/10.1016/j.ecss.2008.11.013.

Doxaran, D., 2009. Télédetection et modélisation numérique des flux sedimentaires dans l'estuaire de la Gironde. l'Université Bordeaux 1, PhD thesis, p. 309. Available online at: omtab.obs-vlfr.fr/personnes/z_doxa_da/Thesis/These Doxaran_short.pdf.

Doxaran, D., Devred, E., Babin, M., 2015. A 50 \% increase in the mass of terrestrial particles delivered by the Mackenzie River into the Beaufort Sea (Canadian Arctic Ocean) over the last 10 years. Biogeosciences 12, 3551-3565. https:// doi.org/10.5194/bg-12-3551-2015.

El Serafy, G.Y., Eleveld, M.A., Blaas, M., van Kessel, T., Aguilar, S.G., Van der Woerd, H.J., 2011. Improving the description of the suspended particulate matter concentrations in the southern North Sea through assimilating remotely sensed data. Ocean Sci. J. 46 (3), 179-204.

Eom, J., Choi, J.-K., Won, J.-S., Ryu, J.-H., Doxaran, D., Ruddick, K., Lee, S., 2016. Spatiotemporal variation in suspended sediment concentrations and related factors of coastal waters based on multispatial satellite data in Gyeonggi Bay, Korea. J. Coast Res. 653-667. https://doi.org/10.2112/JCOASTRES-D-16-00012.1.

Feng $\mathrm{L}, \mathrm{Hu}, \mathrm{C}, \mathrm{Chen}, \mathrm{X}$, Song $\mathrm{Q}, 2014$. Influence of the three Gorges dam on total suspended matters in the Yangtze estuary and its adjacent coastal waters: observations from MODIS. Remote Sens. Environ. 140, 779-788. https://doi.org/ 10.1016/j.rse.2013.10.002.

Froidefond, J.M., Castaing, P., Mirmand, M., Ruch, P., 1991. Analysis of the turbid plume of the Gironde (France) based on SPOT radiometric data. Remote Sens. Environ. 36, 149-163. https://doi.org/10.1016/0034-4257(91)90053-9.

Froidefond, J., Jegou, A.-M., Hermida, J., Lazure, P., Castaing, P., 1998. Variabilité du panache turbide de la Gironde par télédétection. Effets des facteurs climatiques. Oceanol. Acta 21, 191-207.

Froidefond, J.M., Castaing, P., Prud'Homme, R., 1999. Monitoring suspended particulate matter fluxes and patterns with the AVHRR/NOAA-11 satellite: application to the Bay of Biscay. Deep. Res. Part II Top. Stud. Oceanogr 46, 2029-2055. https://doi.org/10.1016/S0967-0645(99)00054-5.

Gangloff, A., Verney, R., Doxaran, D., Ody, A., Estournel, C., 2017. Investigating rhône river plume (Gulf of Lions, France) dynamics using metrics analysis from the MERIS 300m ocean color archive (2002 - 2012). Continent. Shelf Res. https:// doi.org/10.1016/j.csr.2017.06.024.
Gohin, F., Loyer, S., Lunven, M., Labry, C., Froidefond, J.-M., Delmas, D., Huret, M. Herbland, A., 2005. Satellite-derived parameters for biological modelling in coastal waters: illustration over the eastern continental shelf of the Bay of Biscay. Remote Sens. Environ. 95, 29-46.

Gohin, F., 2011. Annual cycles of chlorophyll-a, non-algal suspended particulate matter, and turbidity observed from space and in-situ in coastal waters. Ocean Sci. 7, 705-732. https://doi.org/10.5194/os-7-705-2011.

Goyens, C., Jamet, C., Ruddick, K.G., 2013. Spectral relationships for atmospheric correction. II. Improving NASA's standard and MUMM near infra-red modeling schemes. Optic Express Vol 21 (18), 21176-21187.

He, X., Bai, Y., Pan, D., Huang, N., Dong, X., Chen, J., Chen, C.T.A., Cui, Q., 2013. Using geostationary satellite ocean color data to map the diurnal dynamics of suspended particulate matter in coastal waters. Remote Sens. Environ. 133, 225-239. https://doi.org/10.1016/j.rse.2013.01.023.

Hermida, J., Lazure, P., Froidefond, J.M., Jegou, A.M., Castaing, P., 1998. La dispersion des apports de la Gironde sur le plateau continental. Donnees in situ, satellitales et numeriques. Oceanol. Acta 21, 209-221. https://doi.org/10.1016/S03991784(98)80009-1.

Irigoien, X., Castel, J., 1997. Light limitation and distribution of chlorophyll pigments in a highly turbid estuary: the Gironde (SW France). Estuar. Coast Shelf Sci. 44, 507-517.

Jalón-Rojas, I., Schmidt, S., Sottolichio, A., 2015. Turbidity in the fluvial Gironde Estuary (southwest France) based on 10-year continuous monitoring: sensitivity to hydrological conditions. Hydrol. Earth Syst. Sci. 19, 2805-2819. https:/ doi.org/10.5194/hess-19-2805-2015.

Lafon, V., 2009. Expoitation des données MODIS pour la zone Gironde - MarennesOléron. G.E.O. Transfert. UMR 5805 EPOC, Université Bordeaux 1, document interne, p. 40.

Lazure, P., Jegou, A.M., 1998. 3D modelling of seasonal evolution of Loire and Gironde plumes on Biscay Bay continental shelf. Oceanol. Acta 21, 165-177. https://doi.org/10.1016/S0399-1784(98)80006-6.

Lesueur, P., Tastet, J.P., Marambat, L., 1996. Shelf mud fields formation within his torical times: examples from offshore the Gironde estuary, France. Continent. Shelf Res. 16, 1849-1870. https://doi.org/10.1016/0278-4343(96)00013-1.

Loisel, H., Mangin, A., Vantrepotte, V., Dessailly, D., Ngoc Dinh, D., Garnesson, P. Ouillon, S., Lefebvre, J.P., Mériaux, X., Minh Phan, T., 2014. Variability of suspended particulate matter concentration in coastal waters under the Mekong's influence from ocean color (MERIS) remote sensing over the last decade. Remote Sens. Environ. 150, 218-230. https://doi.org/10.1016/j.rse.2014.05.006.

Neukermans, G., Ruddick, K., Bernard, E., Ramon, D., Nechad, B., Deschamps, P.-Y. 2009. Mapping total suspended matter from geostationary satellites: a feasibility study with SEVIRI in the Southern North Sea. Optic Express 17, 14029 https://doi.org/10.1364/OE.17.014029.

Neukermans, G., Ruddick, K.G., Greenwood, N., 2012. Diurnal variability of turbidity and light attenuation in the southern North Sea from the SEVIRI geostationary sensor. Remote Sens. Environ. 124, 564-580. https://doi.org/10.1016/ j.rse.2012.06.003.

Novoa, S., Doxaran, D., Ody, A., Vanhellemont, Q., Lafon, V., Lubac, B., Gernez, P., 2017. Atmospheric corrections and multi-conditional algorithm for multisensor remote sensing of suspended particulate matter in low-to-high turbidity levels coastal waters. Rem. Sens. 9. https://doi.org/10.3390/rs9010061.

Ody, A., Doxaran, D., Vanhellemont, Q., Nechad, B., Novoa, S., Many, G., Bourrin, F., Verney, R., Pairaud, I., Gentili, B., 2016. Potential of high spatial and temporal ocean color satellite data to study the dynamics of suspended particles in a micro-tidal river plume. Rem. Sens. 8, 245. https://doi.org/10.3390/rs8030245.

Petus, C., Chust, G., Gohin, F., Doxaran, D., Froidefond, J.-M., Sagarminaga, Y., 2010 Estimating turbidity and total suspended matter in the Adour River plume (South Bay of Biscay) using MODIS 250-m imgery. Continent. Shelf Res. 30 379-392.

Petus, C., 2009. Qualité des eaux côtiere du sud du golfe de Gascogne par télédétection spatiale. Méthodologie de détermination et de quantification de substances particulaires et dissoutes. l'Université Bordeaux 1, PhD thesis, p. 409.

Ruddick, K.G., Ovidio, F., Rijkeboer, M., 2000. Atmospheric correction of SeaWiFS imagery for turbid coastal and inland waters. Appl. Optic. 39, 897-912. https:// doi.org/10.1364/A0.42.000893.

Ruddick, K., Neukermans, G., Vanhellemont, Q., Jolivet, D., 2013. Challenges and opportunities for geostationary ocean colour remote sensing of regional seas: a review of recent results. Remote Sens. Environ. 146, 63-76. https://doi.org 10.1016/j.rse.2013.07.039.

Sottolichio, A., Hanquiez, V., Van Maanen, B., Arriagada, J., Jalon Rojas, I., Schmidt, S. Birrien, F., 2014. Evolution hydrosédimentaire récente de l'estuaire de la Gironde. Apport d'un modèle de transport. XIIlèmes Journées Nationales Génie Côtier, Dunkerque (France). https://doi.org/10.5150/jngcgc.2014.055, 2-4 July 2014

Strady, E., Kervella, S., Blanc, G., Robert, S., Yves Stanisière, J., Coynel, A., Schäfer, J., 2011. Spatial and temporal variations in trace metal concentrations in surface sediments of the Marennes Oléron Bay. Relation to hydrodynamic forcing. Continent. Shelf Res. 31, 997-1007. https://doi.org/10.1016/j.csr.2011.03.006.

Vanhellemont, O., Neukermans, G., Ruddick, K., 2014. Synergy between polarorbiting and geostationary sensors: remote sensing of the ocean at high spatial and high temporal resolution. Remote Sens. Environ. 146, 49-62. https://doi.org/10.1016/j.rse.2013.03.035.

Yang, X., Mao, Z., Huang, H., Zhu, Q., 2016. Using GOCI retrieval data to initialize and validate a sediment transport model for monitoring diurnal variation of SSC in Hangzhou Bay, China. Water 8, 108. https://doi.org/10.3390/w8030108. 